\title{
Research into oxide inclusions in silicon bronze CuSi3Zn3MnFe with the use of X-ray microanalysis
}

\section{Badania wtrąceń tlenkowych w brązie krzemowym CuSi3Zn3MnFe metodą mikroanalizy rentgenowskiej}

\begin{abstract}
This paper presents the results of X-ray microanalysis oxide inclusions in silicon bronze in terms of selection microadditions deoxidizers-modifying. On the basis of the oxides present in the alloy, it was found that the most appropriate microadditive is zirconium.
\end{abstract}

Keywords: X-ray microanalysis, deoxidizing-modifying microadditives, silicon bronze

\section{Streszczenie}

W pracy przedstawiono wyniki badań metodą mikroanalizy rentgenowskiej wtrąceń tlenkowych w brązie krzemowym pod względem doboru mikrododatków odtleniająco-modyfikujących. Na podstawie występujących w stopie tlenków stwierdzono, że najodpowiedniejszym mikrododatkiem jest cyrkon.

Słowa kluczowe: mikroanaliza rentgenowska, mikrododatki odtleniająco-modyfikujące, brąz krzemowy

\section{Introduction}

One of the most versatile alloys (which can replace a wide range of tin bronzes under tough conditions) is a multiple silicon-zinc-manganese-iron bronze CuSi3Zn3MnFe. This alloy is characterized by satisfactory corrosion and abrasion resistance, and in terms of mechanical properties, is superior to tin bronzes persists only to high strength aluminum bronzes. For these reasons, it is widely used for the production of machine parts exposed to corrosion and variable loads, industrial valves, water and steam,

Remigiusz Romankiewicz Ph.D. Eng., Ferdynand Romankiewicz Ph.D. D.Sc. Eng.: University of Zielona Gora, Faculty of Mechanical Engineering, Zielona Gora, Poland; r.romankiewicz@ibem.uz.zgora.pl 
hydraulic valve bodies (especially), and valve safety [1]. It is also used for the production of machine parts for the steel industry, working at high loads and elevated temperatures (up to $300^{\circ} \mathrm{C}$ ), as well as slide bearings operating at static load ( $p \cdot v=$ $=11.8 \mathrm{MN} / \mathrm{m}^{2} \cdot \mathrm{m} / \mathrm{s} v_{\max } 4 \mathrm{~m} / \mathrm{s}$ ) [2]. An important advantage of bronze is its suitability for die casting [3].

The disadvantages of silicon bronze may include its high tendency to dissolve gases, and because of the chemically active components (silicon, manganese, zinc, and iron), are also tendency to slag inclusion, that is pollution oxides of alloying elements. This causes a severe reduction in mechanical properties, corrosion, and tribological properties. For this reason, there is a need for research that will allow us to identify the type and morphology of non-metallic inclusions, which can provide a good basis for selecting deoxidizing-modifying microadditives affecting the improvement of the structure and properties of this precious casting alloy constructional. For thermodynamic reasons, there is a possibility of occurrence in the analyzed bronze oxides of iron, zinc, manganese, and silicon oxides mainly.

\section{Methods and results of research}

For the study, was used silicon-zinc-manganese-iron bronze CuSi3Zn3MnFe of geese metallurgical of chemical composition as follows: $3.89 \% \mathrm{Si} ; 3.97 \% \mathrm{Zn} ; 1.39 \% \mathrm{Mn} ; 0.86 \%$ Fe; $0.15 \% \mathrm{Sn} ; 0.04 \% \mathrm{Ni} ; 0.03 \% \mathrm{~Pb} ; 0.02 \% \mathrm{Al} ; 0.01 \% \mathrm{Sb} ; 0.01 \% \mathrm{As} ; 0.01 \% \mathrm{Mg} ; 0.002 \% \mathrm{Bi}$; the rest $\mathrm{Cu}$.

Metallographic examinations were carried out at an angle occurring in bronze oxide inclusions. For this purpose, we used X-ray microanalyzer JXA-50A with the following working conditions: accelerating voltage $25 \mathrm{KV}$; a beam current $(2-6) \cdot 10^{8} \mathrm{~A}$. Under these conditions, the limit of resolution electron image was $10^{-7}-10^{-6} \mathrm{~m}$. The limit of detection elements ranged between $10-2 \%$ for iron and $10-1 \%$ for oxygen. A series of images was made of electron microphotographs (SEI, AEl, and a COMPO TOPO) as well as images of the surface distribution of elements of the characteristic $X$-rays of such elements as copper, silicon, zinc, manganese, iron, aluminum, and oxygen.

The results are illustrated in Figures 1-16. Figure 1 shows an image of oxide inclusions as a secondary electron image (SEI). Figure 2 shows an image of oxide inclusions as an absorptive image indicating the topography of chemical composition (AEI), and Figure 3 presents a picture of the topography of the surface inclusions (TOPO). Figure 4 shows the non-homogeneity of chemical composition of inclusions (COMPO).

Figures 5-10 illustrate the linear distribution of elements such as iron (Fig. 5), manganese (Fig. 6), aluminum (Fig. 7), oxygen (Fig. 8), silicon (Fig. 9), and zinc (Fig. 10). 


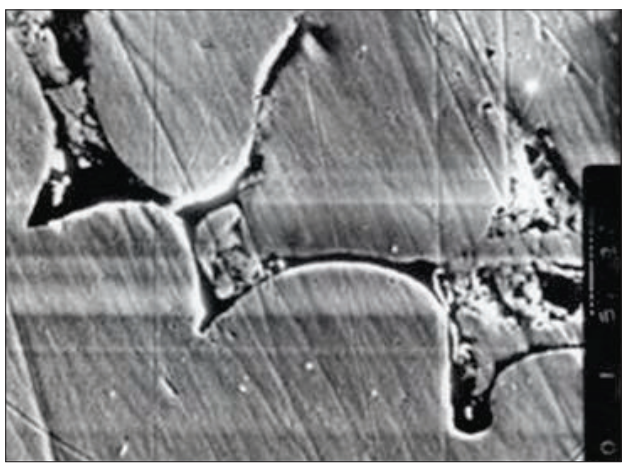

Fig. 1. Scanning image SEl of inclusions in a sample of silicon bronze CuSi3Zn3MnFe ingots metallurgical (magn. 1000x)

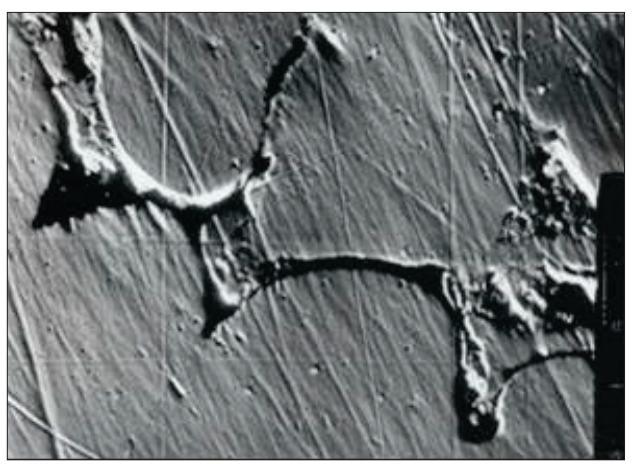

Fig. 3. Scanning image TOPO of inclusions in a sample of silicon bronze CuSi3Zn3MnFe ingots metallurgical (magn. 1000X)

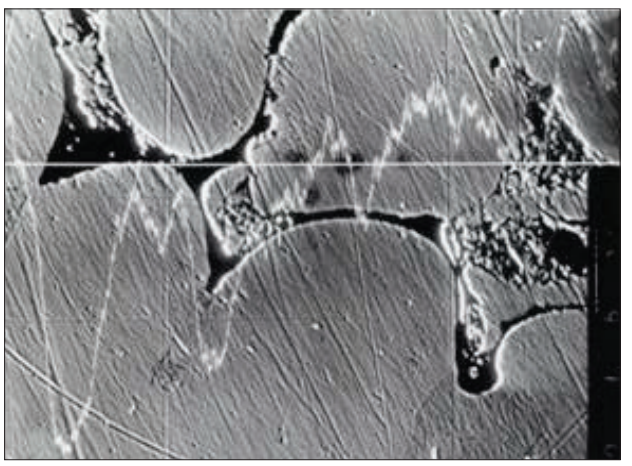

Fig. 5. Scanning image COMPO of inclusions in a sample of silicon bronze CuSi3Zn3MnFe ingots metallurgical illustrating the linear distribution of $\mathrm{Fe}$ (magn. 1000x)

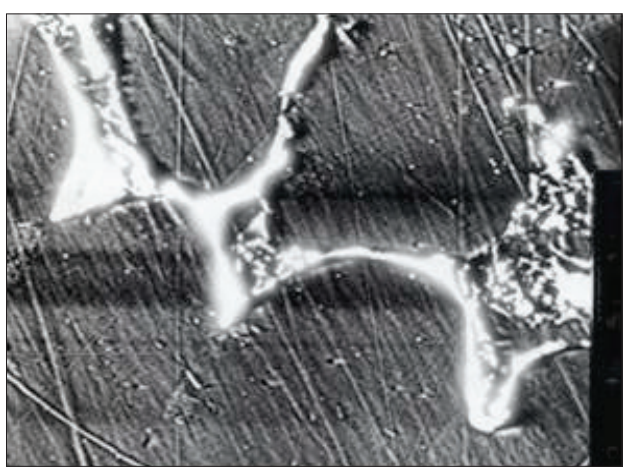

Fig. 2. Scanning image AEl of inclusions in a sample of silicon bronze CuSi3Zn3MnFe ingots metallurgical (magn. 1000x)

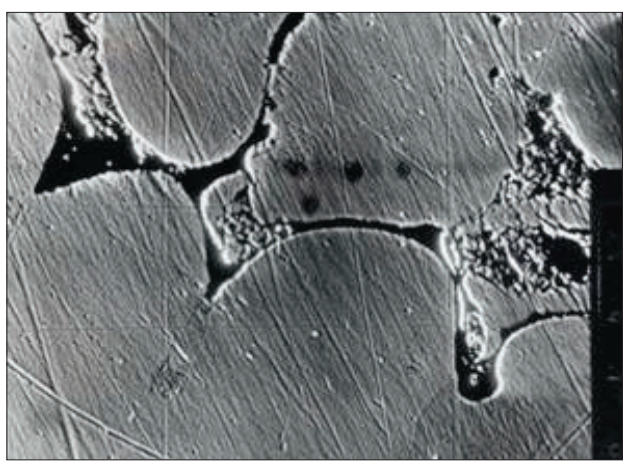

Fig. 4. Scanning image COMPO of inclusions in a sample of silicon bronze CuSi3Zn3MnFe ingots metallurgical (magn. 1000x)

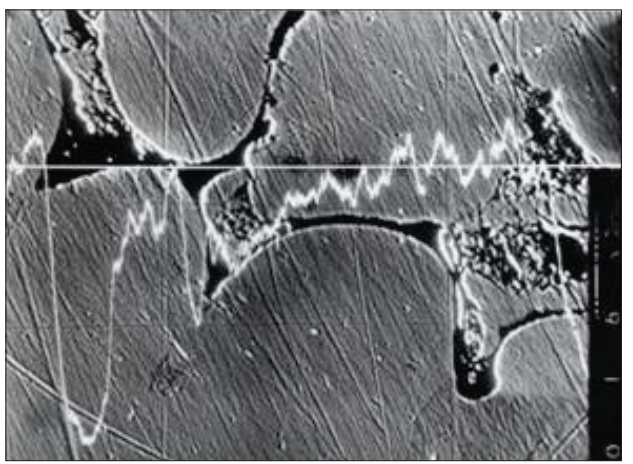

Fig. 6. Scanning image COMPO of inclusions in a sample of silicon bronze CuSi3Zn3MnFe ingots metallurgical illustrating the linear distribution of $\mathrm{Mn}$ (magn. 1000x) 


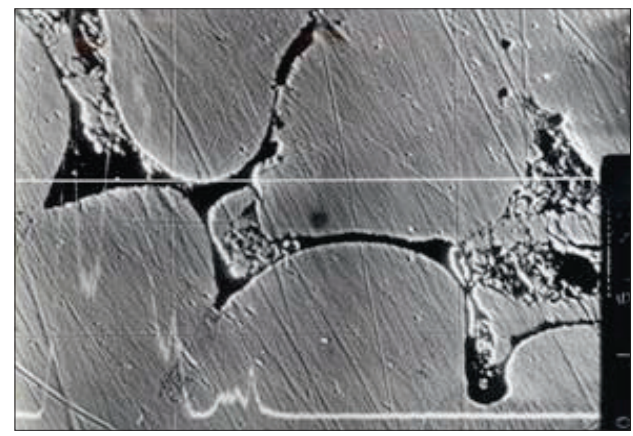

Fig. 7. Scanning image COMPO of inclusions in a sample of silicon bronze CuSi3Zn3MnFe ingots metallurgical illustrating the linear distribution of $A l$ (magn. 1000x)

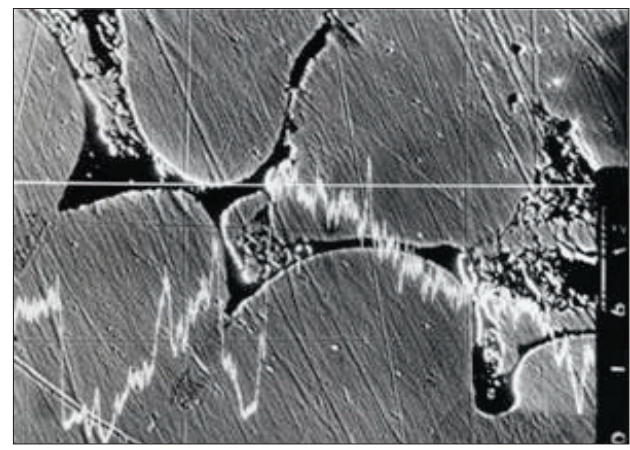

Fig. 9. Scanning image COMPO of inclusions in a sample of silicon bronze CuSi3Zn3MnFe ingots metallurgical illustrating the linear distribution of $\mathrm{Si}$ (magn. 1000x)

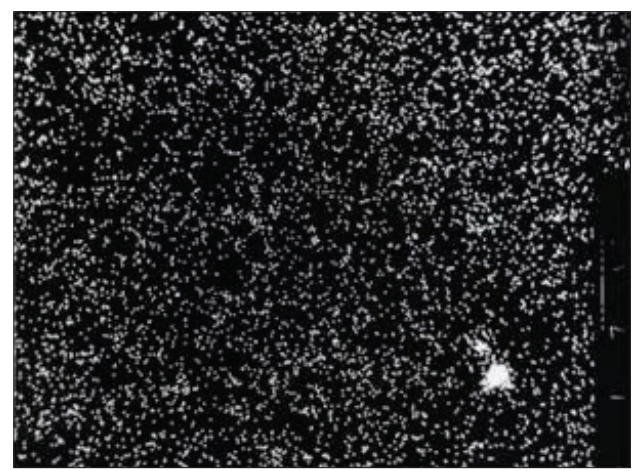

Fig. 11. The surface distribution of iron in silicon bronze CuSi3Zn3MnFe of ingots metallurgical (magn. 1000X)

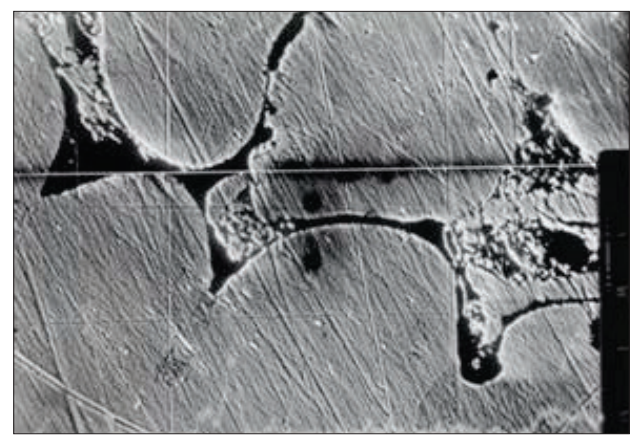

Fig. 8. Scanning image COMPO of inclusions in a sample of silicon bronze CuSi3Zn3MnFe ingots metallurgical illustrating the linear distribution of $O$ (magn. 1000x)

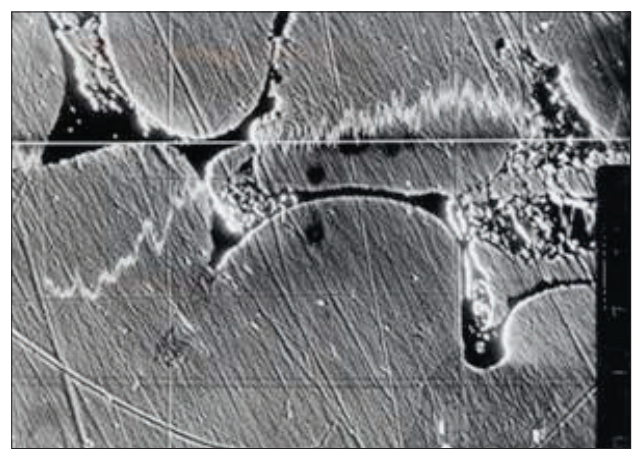

Fig. 10. Scanning image COMPO of inclusions in a sample of silicon bronze CuSi3Zn3MnFe ingots metallurgical illustrating the linear distribution of $\mathrm{Zn}$ (magn. 1000x)

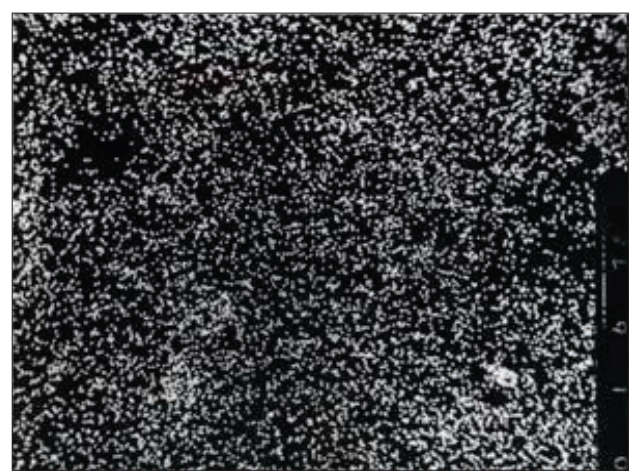

Fig. 12. The surface distribution of manganese in silicon bronze CuSi3Zn3MnFe of ingots metallurgical (magn. 1000X) 
Figures 11-16 illustrate a surface distribution of the following elements: iron (Fig. 11), manganese (Fig. 12), aluminum (Fig. 13), oxygen (Fig. 14), silicon (Fig. 15), and zinc (Fig. 16).

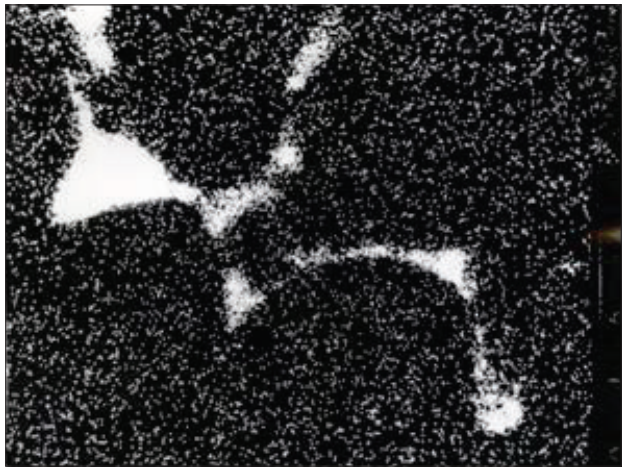

Fig. 13. The surface distribution of aluminum in silicon bronze CuSi3Zn3MnFe of ingots metallurgical (magn. 1000x)

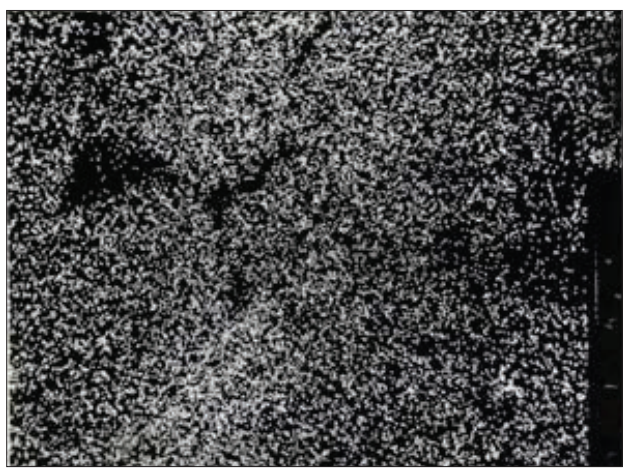

Fig. 15. The surface distribution of silicon in silicon bronze CuSi3Zn3MnFe of ingots metallurgical (magn. 1000x)

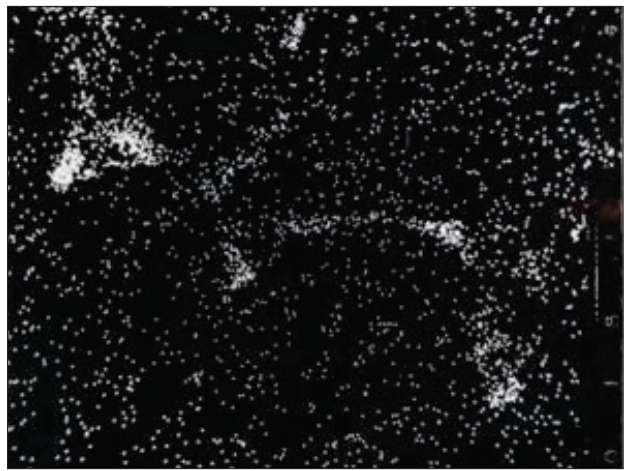

Fig. 14. The surface distribution of oxygen in silicon bronze CuSi3Zn3MnFe of ingots metallurgical (magn. 1000x)

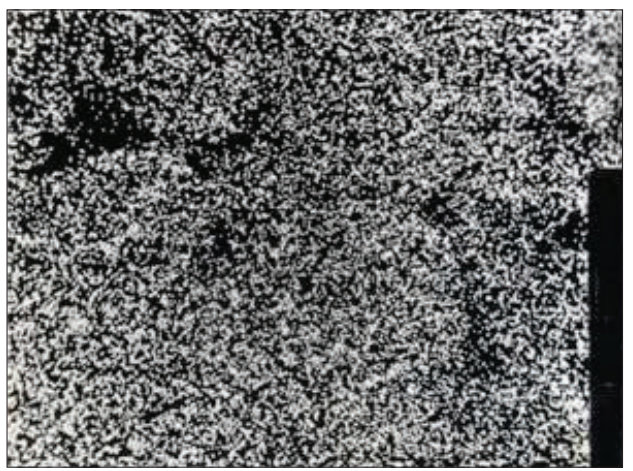

Fig. 16. The surface distribution of zinc in silicon bronze CuSi3Zn3MnFe of ingots metallurgical (magn. 1000X)

\section{Analysis of the results}

The test results show that there are considered complex oxide inclusions on the silicon bronze consisting essentially of oxides of iron, silicon, manganese, and aluminum, as confirmed by the elemental distribution of the surface images (Figs 11-16). There was no discernable presence of oxides of copper and zinc.

Inclusions of oxides of iron, silicon, manganese, and aluminum exhibited sizes $(0.3-1.8) \cdot 10^{-6} \mathrm{~m}$, while the complete cluster sizes reached $(25-35) \cdot 10^{-6} \mathrm{~m}$. 
Based on the findings, you can specify elements that can act as effective scavengers for silicon bronze-zinc-manganese. Thermodynamic analysis made by the authors indicates that the current considered bronze oxides may be reduced by such elements as zirconium, lithium, magnesium, beryllium, and calcium. Taking into account the technical difficulties associated with the strong reactivity of lithium with components of the atmosphere (oxygen and moisture) and the difficulties involved with feather lithium to metal bath in the absence the appropriate master alloys, there are huge difficulties in the practical application of this metal. The use of magnesium for the deoxidation of a copper-silicon alloy in an amount exceeding $0.02 \%$ causes by S. Rzadkosz [4] a reduction in strength properties and increasing brittleness of the alloys. The use of beryllium is hampered because of its strong toxicity and high price. This raises the conclusion that good deoxydants for tested silicon bronze (as well as for other copper-silicon alloys) can be metals such as zirconium and calcium. The use of these metals for the deoxygenation of silicon bronzes is also justified by the fact that previous research by the authors [5] they act as modifiers that cause the fragmentation of the structure of copper alloy, which in relation to the zirconium studies of S. Rzadkosz [4] have also confirmed. The advantage of zirconium over calcium decides the easier availability of initial copper-zirconium alloys.

\section{Conclusions}

Studies of non-metallic inclusions in a silicon-zinc-manganese bronze CuSi3Zn3MnFe carried out by electron microscopy and X-ray microanalysis demonstrated that the inclusions constitute composite oxides of silicon, iron, manganese, and aluminum. This provides a good basis for identifying calcium, especially zirconium as metals recommended for the deoxygenation of silicon bronzes.

\section{References}

[1] Adamski C., Bonderek Z., Piwowarczyk F.: Mikrostruktury odlewniczych stopów miedzi oraz cynku. Wyd. Śląsk, Katowice 1972

[2] Tokarski M.: Metaloznawstwo metali i stopów nieżelaznych w zarysie. Wyd. Śląsk, Katowice 1985

[3] Górny Z., Sobczak J.: Nowoczesne tworzywa odlewnicze na bazie metali nieżelaznych. ZA-PIS, Kraków 2005

[4] Rzadkosz S.: Odlewnictwo miedzi i jej stopów. Wydz. Odlewnictwa AGH, Kraków 2013

[5] Romankiewicz F.: Modyfikacja miedzi i jej stopów. Komisja Nauki o Materiałach PAN, Oddział w Poznaniu, Politechnika Zielonogórska, Poznań-Zielona Góra 1999 